\title{
Floral variety of Fabaceae Lindl. family in gully ecosystems in the south-west of the Central Russian Upland
}

\author{
Vladimir I. Cherniavskih¹, Elena V. Dumacheva², Fedor N. Lisetskii ${ }^{3 *}$, Boris G. Tsugkiev ${ }^{4}$ and \\ Larisa Ch. Gagieva ${ }^{4}$ \\ ${ }^{1}$ Botanical Garden, Belgorod State National Research University, Belgorod, Russia \\ ${ }^{2}$ Department of Biology, Belgorod State National Research University, Belgorod, Russia \\ ${ }^{3}$ Federal and regional centre for aerospace and surface monitoring of the objects and natural resources, \\ Belgorod State National Research University, Belgorod, Russia \\ ${ }^{4}$ Department of Biological and Chemical Technology, Gorsky State Agrarian University, Vladikavkaz, the \\ Republic of North Ossetia-Alania, Russia
}

\section{ABSTRACT}

The multi-year geobotanical studies have shown that in the south-west of the Central Russian Upland the floristic composition of gully ecosystems includes 274 genera, which are combined into 65 families. The species from 3 families: Asteraceae Dumort., Fabaceae Lindl. and Poaceae Barnh. take the lead in the taxon hierarchy. The value of the generic coefficient, which is calculated by the number of species per genus, is quite significant and is equal to 1.81 . It has been established that Fabaceae Lindl. species have extensive presentation (it comes second place in the first triad of families). Among Fabaceae species, a particular importance is given to wild related cultural species, which have high biological, and resource value by a mix of morphological and qualitative characteristics and which are potential selection sources for improvement of various economically useful features. The most striking example include species of the Medicago: Medicago sativa L. genus and the Medicago var Mart. hybrid genus. The M. sativa L. and M. varia Mart. coenopopulations in gully mouths are the most complete and they often have continuity of species distribution by age groups. It has been found that any forms, which act as carriers of multidimensionality recessive mutation, i.e. mf-mutation, have a

\section{ARTICLE INFORMATION:}

Corresponding Author: liset@bsu.edu.ru

Received $20^{\text {th }}$ March, 2019

Accepted after revision $31^{\text {st }}$ May, 2019

BBRC Print ISSN: 0974-6455

Online ISSN: 2321-4007 CODEN: USA BBRCBA

\% Thomson Reuters ISI ESC / Clarivate Analytics USA

\section{Clarivate

$$
\text { Crossref Analytics }
$$

NAAS Journal Score 2019: 4.31 SJIF: 4.196

- A Society of Science and Nature Publication, Bhopal India 2019. All rights reserved.

Online Contents Available at: http//www.bbrc.in/

DOI: $10.21786 / \mathrm{bbrc} / 12.2 / 1$ 
high degree of occurrence in local populations. With seed renewal, the proportion of species with mf-mutation is from 5 to 55\% in families (the offspring of the first plant). The $M$. sativa $L$. and $M$. varia Mart. forms, which have been identified by us in the natural habitats of gully geocomplexes, have a number of valuable selection crop-related characteristics: high seed production, good leaf coverage and high protein content.

KEY WORDS: FLORISTIC COMPOSITION OF PHYTOCENOSES, MEDICAGO SATIVA L., MEDICAGO VARIA MART., MF-MUTATION, MULTIPLICIT

\section{INTRODUCTION}

Due to some, ecological and climatic changes which have been observed in the last decades we have to make a new assessment of flora changes in the regions with ecotones, for example, a forest-steppe zone. Some plant species can actively adapt to any environmental changes thanks to the fact that they are ready to be divided into separate populations, which are tolerant to the conditions of new ecological niches. Even small changes in natural heterogeneous populations cause new systematic taxon's and ecotypes. Their use is of great importance for the creation of a new source material for breeding and the formation of new biological resources (Givnish, 2002).

The form-building process is most active on the territories with complex geological history and a variety of ecological-climatic and soil conditions, in mountainous or foothill areas and in ancient agricultural centres (Takhtajan, 1986, Vavilov, 1992, Goncharov, 2007). The south-west part of the Central Russian Upland largely corresponds to the above-mentioned historical, geographical, ecological and anthropogenic conditions. It is important that the Dneprovskoe and Valdaiskoe glaciation did not affect a significant part of the south-west of the Central Russian Upland. The unique features of the Central Russian Upland landscapes are based on a wide spread of typical karst and cretaceous landscape complexes with involvement of exposed and shallow chalk rocks, which make the region similar to foothills. Therefore, the study region has all the conditions, which accompany primary microevolution processes at the level of microgeocenter (Zhukovsky, 1971, Diamond, 2002, Dumacheva et al., 2015). The recent decline in the share of arable land due to more stringent environmental requirements has created space for the formation of autogenous successions (Lisetskii et al., 2016a) which include both new relationships among plants in communities (Degtyar' and Chernyavskikh, 2006, Gusev, $2016 \mathrm{a}, \mathrm{b})$ and spontaneous changes in plant habitats, including soil reproduction (Lisetskii, 2012, Prikhodko and Manakhov, 2014, Lisetskii et al., 2016b and Terekhin and Chendev, 2018).

The ecological and biological characteristics of the species growing in difficult conditions of gully complexes may be of particular interest as a potential bioresource used to select plants, to obtain starting materials of herbal origin and to improve ecosystems stability. The present paper was aimed to study the floristic composition of natural communities of gully complexes with carbonate outcrops towards the south-west of the Central Russian Upland (on the example of the east of the Belgorod region). We estimated the species composition of the Fabaceae Lindl. family as a possible starting material for selection.

\section{MATERIALS AND METHODS}

Study area: Research was conducted in the Belgorod region in 2002-2016. The climate of the study area is temperate continental. Its main particular features as follows: large annual temperature range, relatively mild winters with frequent thaws and snowfalls, sunny and long summers, moderate and not quite stable moisture with summer precipitation being prevailed (Table 1).

\begin{tabular}{|c|c|c|}
\hline \multirow{2}{*}{ Indicators } & \multicolumn{2}{|c|}{ Weather station } \\
\hline & Valuyki & Alekseevka \\
\hline Rainfall, mm & 568 & 545 \\
\hline Average summer temperature, ${ }^{\circ} \mathrm{C}$ & +20.0 & +20.0 \\
\hline Average winter temperature, ${ }^{\circ} \mathrm{C}$ & -7.0 & -7.5 \\
\hline $\begin{array}{l}\text { Duration of the frost-free period, } \\
\text { days }\end{array}$ & 155 & 155 \\
\hline $\begin{array}{l}\text { The sum of the air } t \text { for the period } \\
\text { with stable } t>10^{\circ} \mathrm{C}\end{array}$ & 2750 & 2700 \\
\hline $\begin{array}{l}\text { The average depth of soil freezing } \\
\text { in winter, } \mathrm{cm}\end{array}$ & 60 & 60 \\
\hline
\end{tabular}

Methods: Natural communities were studied in the course of route studies using the method of intermittent transects and geobotanical descriptions in accordance with the field geobotany procedures (Lavrenko and Korchagin, 1972).

Transects of $400 \mathrm{~m}^{2}(2 \times 200 \mathrm{~m})$ in size were established diagonally to the direction of the gully under study. Four hundreds transects were established in total. P.F. Mayevsky (Mayevsky, 2006) determined the species composition of the plants. Throughout any transect we additionally set up permanent fixed plots with an 
area of $100 \mathrm{~m}^{2}$ (only 400 sites) for geobotanical descriptions, these plots were also used for further geobotanical descriptions of the communities with $M$. sativa $L$. and M. varia Mart. Each species is linked to a certain life form according to the system Raunchier (Raunkiaer, 1937). The florocoenotypes of the Fabaceae Lindl. family and their life forms have been classified of in relation to water (Kolchanov et al., 2012). The species have been distributed with respect to calcium substrate according to V.I. Malyshev (Malyshev, 1965). The occurrence of a species has been defined as a percentage of related geobotanical descriptions. The species names are given in S.K. Szerepanov (Szerepanov, 1981).

\section{RESULTS AND DISCUSSION}

The conducted analysis has shown that the floristic composition of phytocenoses of gully complexes consists of 65 families, which include 274 genera. The species from three families: Asteraceae Dumort., Fabaceae Lindl. and Poaceae Barnh. take the lead in the taxon hierarchy. They account for 161 species (32.8\%) in the floral spectrum, ten leading families include 329 species or $67.0 \%$ of their total number (495 species) (Table 2). The number of families represented by one species is 22 , those of two species - 13 and those of three species - 4. Each of six families contains four species, two families - five species each and 2 another families - seven species each. One family has nine, ten, eleven and twelve species, and two families contain thirteen species each. As for the number of genera, the leading triad of families include Asteraceae Dumort., Brassicaceae Burnett. and Poaceae Barnh. - they account for 77 genera (28.1\%) (Table 2).

A study of ecological features, coenotic and geographical relations has shown that the examined bean species belong to five groups according to geographical confinement. There is a predominance of 20 plant species (44.4\%) of Palearctic areal and 16 species (35.5\%) of steppe area. The European-Caucasian, European and adventive types of geographical areas account for four $(8.8 \%)$, three $(6.6 \%)$ and two $(4.4 \%)$ species respectively.

The generic coefficient (the number of species that per genera) is quite high and it is equal to 1.81 , which reflects the diversity of the floristic composition of the communities of the studied gully complexes.

It has been found that the Fabaceae Lindl. species are quite numerous (they come second in the first triad of families). The $F$. Lindl. family is a valuable source of food and feed protein; it also produces soil symbiotic nitrogen. These species are distinguished by longevity, an exceptional ability to grow in a variety of natural conditions, multipurpose use, soil fertility recovery through atmospheric nitrogen fixation, and a number of other useful economic and biological features. The wild relatives of cultural species become of particular importance as sources for improvement of various economically useful features (Dzyubenko, 2015).

As follows from the analysis of the species composition of the bean component of the phytocenosis of gully complexes 45 species have been detected, i.e. about 58\% of the diversity of the regional flora families (Table 3).

A study of general habit and life cycle duration has shown that taproot redevises tend to prevail among leguminous grasses. There is maximum 13.2\% of annual and biennial plants and $17.6 \%$ of shrubs, sub-shrubs and dwarf sub-shrubs in gully complexes. A variety of ecological conditions, which have formed bean family species in gully complexes, is quite sufficiently shown by the spectrum of life forms. We have revealed that the majority of species (84.5\%) belongs to hemicryptophytes - perennial herbaceous plants with aboveground sprouts being died away by wintertime. Their reproduc-

\begin{tabular}{|c|c|c|c|c|}
\hline \multirow{2}{*}{ Family } & \multirow{2}{*}{ Family rank } & \multirow{2}{*}{ Number of genera } & \multicolumn{2}{|c|}{ Number of species } \\
\hline & & & pieces & $\%$ \\
\hline Asteraceae Dumort. & 1 & 38 & 72 & 14.6 \\
\hline Fabaceae Lindl. & 2 & 17 & 45 & 9.1 \\
\hline Poaceae Barnh. & 3 & 22 & 44 & 9.0 \\
\hline Lamiaceae Lindl. & 4 & 21 & 37 & 7.5 \\
\hline Brassicaceae Burnett & 5 & 23 & 34 & 6.9 \\
\hline Rosaceae Juss. & 6 & 17 & 25 & 5.1 \\
\hline Scrophulariaceae Juss. & 7 & 8 & 22 & 4.5 \\
\hline Caryophyllaceae Juss. & 8 & 11 & 19 & 3.9 \\
\hline Ranunculaceae Juss. & 9 & 10 & 18 & 3.7 \\
\hline Boraginaceae Juss. & 10 & 9 & 13 & 2.6 \\
\hline Total & 65 & 274 & 495 & 100 \\
\hline
\end{tabular}


Table 3. Species composition of the family Fabaceae in gully complexes with chalk outcrops (2002-2013)

\begin{tabular}{|c|c|c|c|c|}
\hline No & Latin species name & Life form ${ }^{\mathrm{a}}$ & florocenotic $^{b}$ & Environmental group ${ }^{c}$ \\
\hline 1 & Anthyllis vulneraria $\mathrm{L}$. & $\mathrm{HC}$ & MD & $\mathrm{MX}$ \\
\hline 2 & Astragalus albicaulis DC. & HC & ST & $\mathrm{X}$ \\
\hline 3 & Astragalus austriacus Jacq. & $\mathrm{HC}$ & ST & MX \\
\hline 4 & Astragalus cicer $\mathrm{L}$. & $\mathrm{HC}$ & MD & MX \\
\hline 5 & Astragalus danicus Retz. & $\mathrm{HC}$ & ST & MX \\
\hline 6 & Astragalus dasyanthus Pall. & HC & ST & MX \\
\hline 7 & Astragalus glycyphyllos L. & $\mathrm{HC}$ & GB & M \\
\hline 8 & Astragalus onobrychis L. & $\mathrm{HC}$ & ST & $\mathrm{X}$ \\
\hline 9 & Astragalus pubiflorus DC. & $\mathrm{HC}$ & ST & $\mathrm{X}$ \\
\hline 10 & Astragalus sulcatus L. & HC & MD & $\mathrm{X}$ \\
\hline 11 & Astragalus ucrainicus M. Pop. et Klok. & $\mathrm{HC}$ & MO & $\mathrm{X}$ \\
\hline 12 & Astragalus varius S.G. Gmel. & $\mathrm{HC}$ & SAN & MX \\
\hline 13 & Caragana frutex (L.) C. Koch & $\mathrm{PH}$ & MD & $\mathrm{X}$ \\
\hline 14 & Chamaecytisus austriacus (L.) Link & $\mathrm{PH}$ & $\mathrm{CH}$ & $\mathrm{MX}$ \\
\hline 15 & Chamaecýtisus ruthénicus (Fisch. ex Woloszcz.) Klaskova & $\mathrm{PH}$ & SAN & MX \\
\hline 16 & Coronilla varia $\mathrm{L}$. & $\mathrm{HC}$ & ST & $\mathrm{M}$ \\
\hline 17 & Genista tanaitica P. Smirn. & HC & $\mathrm{CH}$ & $\mathrm{M}$ \\
\hline 18 & Genista tinctoria $\mathrm{L}$. & $\mathrm{PH}$ & MD & MX \\
\hline 19 & Hedysarum grandiflorum Pall. & $\mathrm{HC}$ & $\mathrm{CH}$ & MX \\
\hline 20 & Lathyrus pannonicus (Jacq.) Garcke & $\mathrm{HC}$ & ST & MX \\
\hline 21 & Lathyrus pallescens (Bieb.) C. Koch & HC & ST & MX \\
\hline 22 & Lathyrus pratensis L. & $\mathrm{HC}$ & MD & M \\
\hline 23 & Lathyrus tuberosus L. & $\mathrm{HC}$ & SYN & MX \\
\hline 24 & Lotus corniculatus L. & HC & MD & M \\
\hline 25 & Medicago falcata L. subsp. romanica (Prodan) Schwarz et Klinkovski & HC & ST & $\mathrm{MX}$ \\
\hline 26 & Medicago lupulina $\mathrm{L}$. & $\mathrm{HC}$ & SAN & $\mathrm{M}$ \\
\hline 27 & Medicago varia Mart. & $\mathrm{HC}$ & SYN & MX \\
\hline 28 & Melilotus albus Medik. & $\mathrm{HC}$ & ST & MX \\
\hline 29 & Melilotus officinalis (L.) Pall. & $\mathrm{HC}$ & ST & MX \\
\hline 30 & Onobrychis arenaria (Kit.) DC. & $\mathrm{HC}$ & ST & MX \\
\hline 31 & Ononis arvensis $\mathrm{L}$. & $\mathrm{HC}$ & MD & M \\
\hline 32 & Oxytropis pilosa (L.) DC. & $\mathrm{HC}$ & ST & $\mathrm{X}$ \\
\hline 33 & Robinia pseudoacacia L. & $\mathrm{PH}$ & SYN & MX \\
\hline 34 & Trifolium alpestre L. & $\mathrm{HC}$ & MD & MX \\
\hline 35 & Trifolium arvense $\mathrm{L}$. & $\mathrm{T}$ & MD & MX \\
\hline 36 & Trifolium fragiferum $\mathrm{L}$. & $\mathrm{HC}$ & MD & MH \\
\hline 37 & Trifolium hybridum $\mathrm{L}$. & $\mathrm{HC}$ & MD & MH \\
\hline 38 & Trifolium medium $\mathrm{L}$. & HC & MD & $\mathrm{M}$ \\
\hline 39 & Trifolium montanum $\mathrm{L}$. & $\mathrm{HC}$ & MD & MX \\
\hline 40 & Trifolium pratense $\mathrm{L}$. & $\mathrm{HC}$ & MD & M \\
\hline 41 & Trifolium repens L. & $\mathrm{HC}$ & MD & M \\
\hline 42 & Trifolium aureum Poll. & $\mathrm{HC}$ & MD & MX \\
\hline 43 & Vicia cassubica L. & $\mathrm{HC}$ & FR & M \\
\hline 44 & Vicia cracca L. & $\mathrm{HC}$ & MD & MX \\
\hline 45 & Vicia villosa Roth. & $\mathrm{T}$ & MD & MX \\
\hline
\end{tabular}




\begin{tabular}{|l|l|l|l|l|}
\hline Table 4. Distribution of Fabaceae species in gully complexes depending on relief elements (2008-2013) \\
\hline Sampling point & mesophyte & mesoxerophyte & mesogigrophyte & xerophyte \\
\hline Slopes of beams with steppe phytocenosis & 1 & 7 & - & 3 \\
\hline Slopes of beams with lime-loving association & - & 4 & - & 4 \\
\hline Ravine mouths with alluvial cone & 4 & 8 & - & - \\
\hline Alluvial cone acting ravines & 6 & 7 & 2 & - \\
\hline Total & 11 & 25 & 2 & 7 \\
\hline
\end{tabular}

ing buds are located on the soil surface and protected by leaf litter. Phanerophytes and Therophytes are generally represented by $15.5 \%$ of species in the regional gully complexes. The bean species distribution in gully complexes is largely determined by soil moisture. An analysis of species-to-moisture factor ecological spectrum has shown that the species (55.5\%) predominantly belong to mesoxerophytes, i.e. plants, which are able to tolerate a short-term drought. As for the number of species mesophytes, xerophytes and mesohygrophytes take the second, third and fourth places, respectively.

Various manifestations of calcephilia, which is related with calcium excess and substrate carbonate content have made it possible to distribute bean species by plant confinement to calcium substrate according to the classification by V.I. Malyshev (Malyshev, 1965). The bean gully complexes $(73.3 \%)$ are prevailed by facultative calciphile plants, which are quite common on carbonate soils but can also grow outside. A group of calcium-indifferent bean plants (17.8\%) include the species which are either unobviously confined to carbonate substrates or fail to be calciphobes. We have found $8.9 \%$ of obligatory calciphile plant, which grow almost exclusively on the calcium substrate. Under severe environmental conditions a combination of resources in a particular ecotope point is of critical importance for coenopopulations. The gully complexes have a well-defined micro-relief, which has impact on spatial distribution of species. $60.0 \%$ of mesophytic bean species are concentrated on the rank soils in ravine mouths and existing gully cone deltas, i.e. in more humid living environment. On gully slopes with steppe plant formations there are $20.0 \%$ of xerophytic and mesoxerophytic species whereas slopes with calciphilous communities have 15.5\% of them (Table 4).

In general, in the conditions of gully complexes the ecological features of bean plants are characterized by the predominance of mesoxerophytes and facultative calciphile plants as regards ecotope conditions and steppe florocenotype hemicryptophytes by life form.

The landscape conditions of the gully complex ecotopes with cretaceous outcrops tend to create conditions for the introduction of new synanthropic species and their active formation. Many species may be of high bio-resource value. The most striking example include species of the Medicago genus: $M$. sativa $\mathrm{L}$. and hybrid
M. varia Mart. species.The history of wide distribution of these species, which are mainly of Central Asian and Mediterranean origin in the conditions of the Central Russian Upland, goes back about one hundred years. It is noteworthy that there is not a single record of blueflowered and variegated-flowered M. sativa L. and $M$. varia Mart. species ("native" type alfalfa) in the detailed geobotanical descriptions of gully complexes with cretaceous outcrops which were made $>100$ years ago V.I. Taliev (1904a) (Taliev, 1904b, Juan et.al., 1993).

Currently the M. sativa L. and M. varia Mart. species make an essential and integral component of natural herbaceous phytocenoses. The studies conducted in 20082013 and repeated in 2014-2016 showed that an average increase in the occurrence of these species had made up to from 3.2 to $4.5 \%$ for all geobotanical descriptions, with the most significant increase being demonstrated by the plant communities located on the Cretaceous outcrops (Table 5). In 2008-2013, the steppe areas and meadows were characterized by discrete (incomplete) local populations, which are mainly represented by oldaged blueing and non-blueing individual plants. However, in 2014-2016 some even-aged young plants were also reported to appear for seed regeneration.

In vegetation communities of chalk, outcrops the $M$. sativa L. and $M$. varia Mart. coenopopulations are subject to habitual areas, which have been earlier connected with human economic activities: locations of former farms, marginal plots on fields used for farm and soil conservation crop rotations.A more detailed study of the occurrence of blue-flowered alfalfa in gully complexes

\begin{tabular}{|l|l|l|}
\hline \multicolumn{3}{|l|}{$\begin{array}{l}\text { Table 5. Occurrence of M. sativa L. and M. varia } \\
\text { Mart. in natural association, \% }\end{array}$} \\
\hline \multirow{2}{*}{ Association } & \multicolumn{2}{|l|}{ Years of research } \\
\cline { 2 - 3 } & $\mathbf{2 0 0 8 - 2 0 1 3}$ & $\mathbf{2 0 1 4 - 2 0 1 6}$ \\
\hline Meadow steppes & 2.0 & 3.6 \\
\hline Real steppes & 3.0 & 3.5 \\
\hline Calciphilous steppes & 4.0 & 6.2 \\
\hline Chalk outcrops & 5.0 & 7.1 \\
\hline Meadows & 2.0 & 2.0 \\
\hline Average & 3.2 & 4.5 \\
\hline
\end{tabular}




\begin{tabular}{|l|l|l|}
\hline \multicolumn{3}{|l}{$\begin{array}{l}\text { Table 6. Occurrence of M. sativa } \text { L. and M. varia Mart. } \\
\text { in ecotopes of ravine complexes, \% }\end{array}$} \\
\cline { 2 - 4 } Ecotopes & \multicolumn{2}{l}{ Study years } \\
\cline { 2 - 4 } & $2008-2013$ & $2014-2016$ \\
\hline $\begin{array}{l}\text { Slopes of beams with steppe } \\
\text { association }\end{array}$ & 0.0 & 0.2 \\
\hline $\begin{array}{l}\text { Slopes of beams with lime- } \\
\text { loving association }\end{array}$ & 3.0 & 2.5 \\
\hline $\begin{array}{l}\text { Ravine mouths with alluvial } \\
\text { cone }\end{array}$ & 8.0 & 11.2 \\
\hline Alluvial cone acting ravines & 7.0 & 9.1 \\
\hline Average & 4.5 & 5.6 \\
\hline
\end{tabular}

and its dynamics has made it possible to identify the ecotopes with the most favourable conditions for the development of $M$. sativa L. and M. varia Mart. and for the formation of their stable populations (Table 6).
The occurrence of blue-flowered alfalfa is higher in lower gullies (in the existing gully cone deltas and in the ravine mouths with cone deltas) for a number of possible reasons. Firstly, due to the transfer of seeds through ecotonic corridors being gully slopes. Secondly, due to the particular features of the soil substrate (chalk residues), which forms high-degree crushing, low projective cover and, therefore, low distribution of cereals and lower inter-species competition. Thirdly, due to the influence of natural selection of sustainable forms in the hybrid populations which have formed in the ravine mouths with the varieties of $M$. sativa $L$. and $M$. varia Mart. and local forms of $M$. falcata L. which were previously cultivated on the arable land.

Local coenopopulations of $M$. sativa $L$. and M. varia Mart. are most complete in ravine mouths and they often have species distributed by age groups on a continuous basis. We have found a wide variation of all

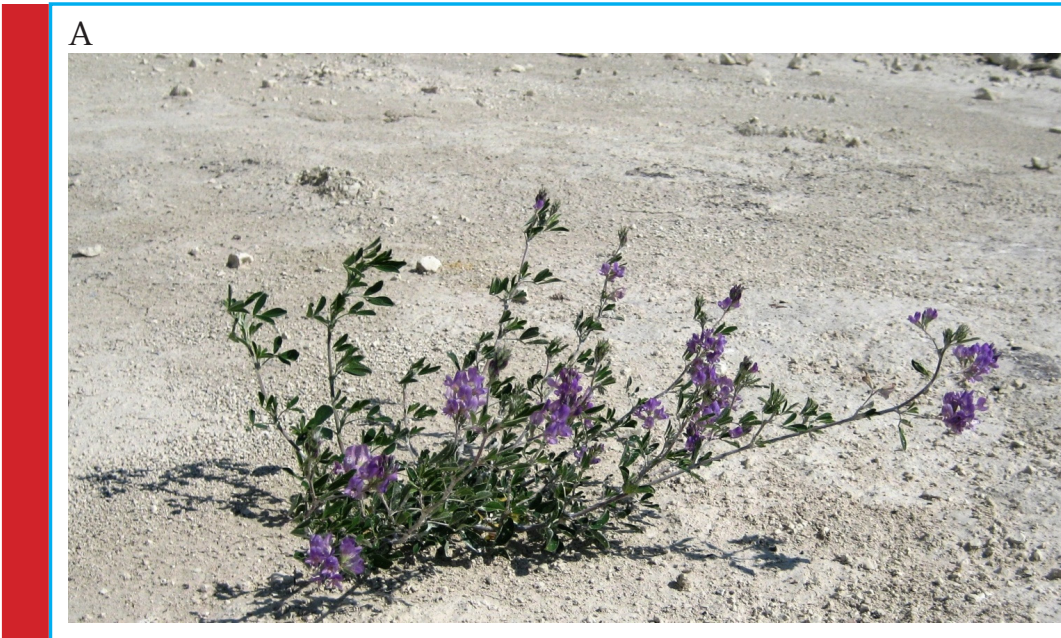

B

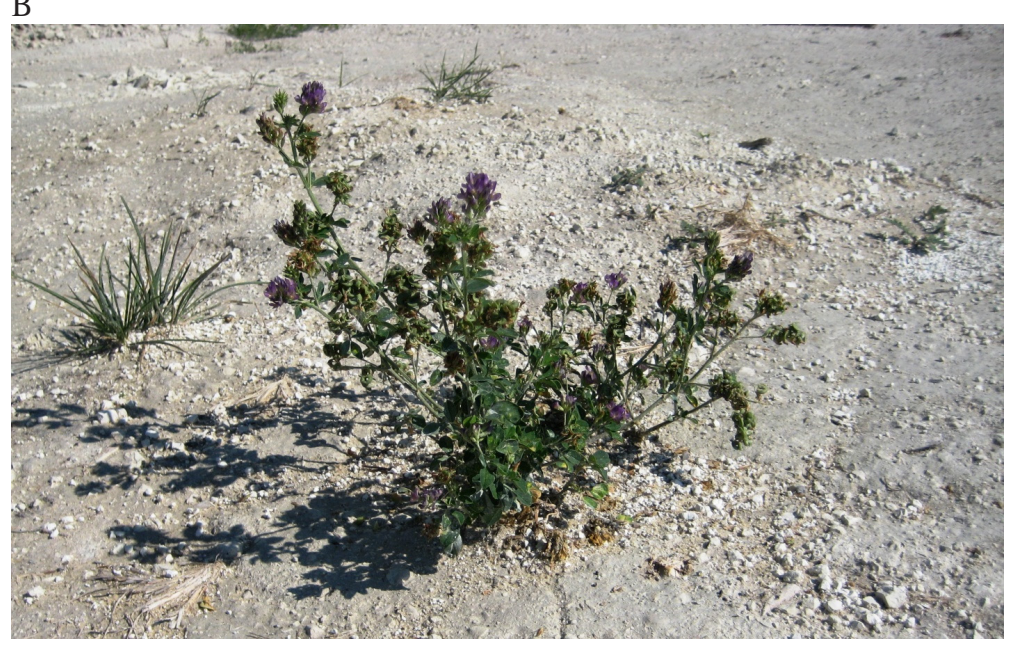

FIGURE: Species M. varia Mart. "Carbonate" environmental type in the flowering phase (A) and fruit formation (B) on alluvial cone ravines 
main morphometric parameters, which proves alfalfa's intrapopulation heterogeneity and ecological plasticity. Hence, these two species provide material for the selection of competitive forms. Adaptive transformations are oriented towards the preservation of individual plants accompanied by a specific increase in leaf coverage, a reduction of generative organs with increased numbers of stemmed beans, bean curls and their dissemination. There has been observed the formation of M. sativa $\mathrm{L}$. and $M$. varia Mart. coenopopulations with individual plants of "carbonate" ecotype, which is close to cultural forms by a number of morphological features but has a pronounced stress-tolerant type of adaptive strategy (Figure). The upper slope seeds (these are usually fields of crop rotations) used to be transferred by water flow to the bottom of the gullies where they fell on rubble chalk eluvium. A vegetation cover with low projective coating was formed in the cone deltas. There alfalfa found favourable conditions for its growth and development in conditions of low competition with cereals. Against the background of negative influence produced by carbonate substrate, primarily, due to iron deficiency, the population have quite promptly eliminated unstable forms and generated M. sativa L. and M. varia Mart. coenopopulations with high level of preservation of individual plants having a complete spectrum of adaptive changes. They have become the basis for microevolution transformations under extreme ecotope conditions. The local populations were reported to have high occurrence of forms carrying multifoliolate recessive mutation (mfmutations). Externally, it is expressed by the formation of complex leaves with 4-7 leaflets in individuals instead of three. These forms are positioned as sources of highquality material for the selection of high-quality cultural alfalfa (Juan, 1993, Petkova, 2010, Odorizzi et al., 2015).

The researchers consider the emerging multi-leafness in leguminous grasses as a throwback, i.e. atavism, which is most strongly manifested in the conditions of disturbed habitual areas when they grow outside the phytocenosis, on poor rocky soils, rock outcrops and in the areas being far from the optimal conditions (Plennik, 2002).An estimation of the populations by the method of transfer into favourable conditions have shown that the share of mf-mutant forms is from 3.3 to 53.3\% in different populations. With seed renewal, the proportion of species with mf-mutation (the offspring of the first plant) is from 5 to $55 \%$ in families.

It is important that the M. sativa L. and M. varia Mart. forms, which have been found in the habitual areas of gully complexes, have a number of valuable crop selection features: good leaf coverage, high protein content and high seed production and others.

\section{CONCLUSION}

We have found a high variety of plant species with high biological potential in the gully complexes in the southern-west part of the Central Russian Upland. It is possible to have accumulations of stable viable recessive forms of individual species, which can be used to generate initial selection material. The example of $M$. sativa L. and M. varia Mart. was used to establish the formation process for coenopopulations of certain sustainable ecotype, which is close to cultural forms, by a number of morphological and qualitative characteristics. The populations studied are characterized by high occurrence of mutant forms (recessive mf-mutation). This phenomenon becomes obvious in the course of development of natural local populations along the boundaries of species distribution areas.

\section{ACKNOWLEDGEMENTS}

The study was supported within the intra-university grant of Belgorod State National Research University to support the creation and development of scientific departments - centres of excellence.

\section{REFERENCES}

Degtyar', O.V. and Chernyavskikh, V.I. (2006). The environment-forming role of endemic species in calciphilous communities of the southern Central Russian Upland. Russ J Ecol, 37(2): 143-145.

Diamond, J. (2002). Evolution, consequences and future of plant and animal domestication. Nature, 418(6898): 700-707.

Dumacheva, E.V., Cherniavskih, V.I., Markova, E.I., Klimova, T.B. and Vishnevskaya, E.V. (2015). Spatial pattern and age range of ceno populations Medicago L. in the conditions of gullying of the southern part of the Central Russian Upland. Res J Pharm Biol Chem Sciences, 6(6): 1425-1429.

Dzyubenko, N.I. (2015). Genetic resources of cultivated plants as the basis for Russia's food and environmental security. Herald of the Russian Academy of Sciences, 85(1): 15-19.

Givnish, T.J. (2002). Ecological constraints on the evolution of plasticity in plants. Evolutionary Ecology, 16: 213-242.

Goncharov, N.P. (2007). Centers of origin of cultivated plants. Bulletin of the All-Russian Society of Genetics and Breeders, 11(3/4): 561-574.

Gusev, A.V., Ermakova, E.I. and Buryak, Z.A. (2016a). Scientific rationale for inclusion of a new nature complex Belyj Kolodez (Russia, Belgorod Region) into the Emerald network. Res J Pharm Biol Chem Sciences, 7(4): 496-501.

Gusev, A.V., Lisetskii, F.N. and Ermakova, E.I. (2016b). Principles and experience of justification of ecological representa- 
tiveness of Emerald network potential sites. Res J Pharm Biol Chem Sciences, 7(2): 1172-1189.

Juan, N.A., Sheaffer, C.C. and Barnes, D.K. (1993). Temperature and photoperiod effects on multifoliolate expression and morphology of alfalfa. Crop science, 33(3): 573-578.

Kolchanov, R.A., Kolchanov, A.F. and Ngo Thy Siem Kieu (2012). The family Fabaceae in flora of the Belgorod region. Nauch. Ved. Belgorod. Gos. Univ., Ser. Estestv. Nauki., 3: 36-49.

Lavrenko, E.M. and Korchagin, A.A. (1972). Field Geobotany. Academy of Sciences of the USSR. Komarov Botanical Institute. Publishing house "Nauka", Leningrad, 336.

Lisetskii, F.N. (2012) Soil reproduction in steppe ecosystems of different ages. Contemp Probl Ecol, 5(6): 580-588. http:// dx.doi.org/10.1134/S1995425512060108

Lisetskii, F.N., Smekalova, T.N. and Marinina, O.A. (2016 a). Biogeochemical features of fallow lands in the steppe zone. Contemp Probl Ecol, 9(3): 366-375. http://dx.doi.org/10.1134/ S1995425516030094

Lisetskii, F.N., Sudnik-Wojcikowska, B. and Moysiyenko, I.I. (2016). Flora differentiation among local ecotopes in the transzonal study of forest-steppe and steppe mounds. Biol Bull, 43(2): 169-176.

Malyshev, V.I. (1965). Alpine Flora of the Eastern Sayan. Science, Moscow-Leningrad, 368.

Mayevsky, P.F. (2006). Flora of the middle zone of the European part of the USSR. KMK Scientific Press, Moscow, 600.

Odorizzi, A., Mamani, E.M.C., Sipowicz, P., Julier, B., Gieco, J. and Basigalup, D. (2015). Effect of phenotypic recurrent selection on genetic diversity of non-dormant multifoliolate lucerne (Medicago sativa L.) populations. Crop and Pasture Sci, 66(11): 1190-1196.
Petkova, D. (2010). Multifoliate Alfalfa line with 23-24 leaves on a leaf stalk. Journal of Crop and Weed, 6(1): 1-5.

Plennik, R.Ya. (2002). Strategies of biomorphological microevolution of the polymorphic species Medicago falcata L. in Siberia. Science, Novosibirsk, 94.

Prikhodko, V.E. and Manakhov, D.V. (2014). Transformation of the organic matter of steppe soils of the Trans-Ural region after their conversion into the reserved regime. Eurasian Soil Sci., 47(4): 236-244. http://dx.doi.org/10.1134/S1064229314020082

Raunkiaer, C. (1937). Plant life forms. Transl. by H. Gilbert-Carter. Clarendon Press, Oxford, 104.

Szerepanov, S.K. (1981). Plantae Vasculares URSS. Nauka, Leningrad, 510.

Takhtajan, A. (1986). Floristic regions of the world. Transl. from Russ. T.J. Cravello, ed. A. Cronquist. Univ. California Press, London, 522.

Taliev, V.I. (1904a). Vegetation of Cretaceous outcrops in southern Russia. Part I. Proceedings of the Society of Testers of Nature at the Imperial University of Kharkov, 39(1): 81-254.

Taliev, V.I. (1904b). Vegetation of Cretaceous outcrops in southern Russia. Part II. Proceedings of the Society of Testers of Nature at the Imperial University of Kharkov, 40(1): 1-282.

Terekhin, E.A. and Chendev, Yu.G. (2018). Estimation of forest cover changes during modern period in the south of the Central Russian Upland using multiyear remote sensing data. Sovremennye Problemy Distantsionnogo Zondirovaniya Zemli iz Kosmosa, 15(3): 114-126.

Vavilov, N.I. (1992). Origin and geography of cultivated plants. Transl. by Doris Love. Cambridge Univ. Press, Cambridge, 498.

Zhukovsky, P.M. (1971). Cultivated plants and their relatives. (Systematics, geography, cytogenetics, ecology, origin, use). Kolos, Leningrad, 752. 